\title{
Service Learning in Sustainable Lighting: A Field Study Engaging Populations High in Rural Native Americans
}

\author{
Celia Stall-Meadows \\ College of Human Environmental Science \\ Oklahoma State University \\ celia@okstate.edu \\ Paulette R. Hebert \\ College of Human Environmental Science \\ Oklahoma State University \\ paulette.hebert@okstate.edu \\ Sylvia Chaney \\ Department of Design, Housing, and Merchandising \\ Oklahoma State University \\ sylvia.chaney@okstate.edu
}

\begin{abstract}
The project engaged students in sustainable lighting education and involved them in rural United States communities with high Native American populations. As part of a research grant, faculty developed a service learning curriculum. Students were taught how to measure and document existing lighting conditions, including ultraviolet light levels in state-owned historic homes filled with museum artifacts. Students worked under the supervision of museum staff. Students also provided sustainable lighting education to local consumers who were residents of lower income communities. Although study participants consistently ranked incandescent light highest in positive lighting attributes, compact fluorescent light ranked a close second. Student demonstrations of sustainable lighting were integral to consumer education and as a result of these student-led educational sessions more participants agreed to consider purchasing compact fluorescent lights instead of incandescent bulbs. Thousands of consumers beyond the study participants were reached through exposure at the U.S. Environmental Protection Agency National Student Design Expo and a permanently-linked video documentary of the research process.
\end{abstract}

Index Terms- Service learning; sustainability; consumer attitudes; sustainable lighting; residential field experience

\section{INTRODUCTION}

Service learning offers a hands-on method of incorporating technical education into community service. The two primary objectives of this service learning research project were (1) to engage students in a professional partnership that taught them how to measure and document ultraviolet (UV) light levels and (2) to develop a student-led public education program that informed Native American residents and other consumers in marginalized rural communities about sustainable lighting. Due to the large percentage of Native Americans in the general population of the state, this specific population was targeted. Two sites were selected for this project: a historic museum home (Site A) and a historic state-owned home (Site B). Site A was a historic home currently serving as a museum, maintained and preserved by the state, which displayed many historic 
artifacts for the enjoyment and education of the public. Site B was a historic home currently serving as a university president's home, also maintained by the state. The service learning research project benefitted the sites' staff, rural consumers, students, and the general population. The museum staff benefitted from access to the study's documented UV data that may aid them in artifact preservation. The community and the general population benefitted from an educational program that informed and encouraged consumers to adopt sustainable lighting that reduced energy consumption and offered substantial savings. The students benefitted by learning real-world applications of lighting sources, including visual effects in situ, energy consumption, cost implications, and non-visual effects of lighting, while providing outreach to others. The incorporation of service learning into a research project and its effects on these groups are discussed in this paper.

Some consumers may be reluctant to pay the higher initial prices of CFL or LED bulbs, although these bulbs have been shown to (or are anticipated to) lower energy bills compared to incandescent. Past studies show that in the United States and other countries, the high initial price of CFLs was one of the main barriers to adoption ${ }^{10,12,14,16}$. In spite of this barrier to adoption, one of the most effective methods for decreasing household electricity consumption is to change from non-sustainable incandescent light bulbs to more sustainable compact fluorescent light (CFL) bulbs ${ }^{1,15}$. Approximately 17 percent of the energy consumption in the U.S. is used for residential lighting and 85 percent of this residential lighting energy consumption is from incandescent bulbs ${ }^{2}$. Additional consumer education is needed to encourage all consumers to adopt more sustainable lighting, in order to reduce energy demands and solid waste.

This research project challenged students to engage in a service learning project that enhanced their critical thinking skills. A field study was planned and implemented that documented existing UV conditions and encouraged sustainable lighting adoption among residents in lower income rural communities and communities with significant percentages of Native Americans. Sites were chosen that allowed public access and, at least to some extent, replicated a residential environment. Public access was desired, in order to draw as large and diverse a sample group as possible. Residential qualities were desired, in order to enhance both the comfort level of the participants and their ability to transfer and apply the information they acquired on-site to their own homes. These sites were selected, due to availability of these facilities to researchers and the general public and their proximity to the researchers. Both sites were located in rural counties that ranked above the national average for Native American populations and below the national average for household incomes. Many of the households in these counties fell below the poverty line.

Researchers have suggested that service learning is a way to bridge academic studies and community service ${ }^{4}$. Other researchers explain that when the activities of service and learning are combined together, the result is added value to each and a transformation of both service and learning ${ }^{7}$. A number of researchers stress that although each service learning project is designed to attain a set of goals that may be unique to the particular project, all service learning projects should benefit both the providers or students and the recipients or community members ${ }^{3,5,6}$.

\section{METHOD}

\section{Study Design}

The research was managed by student-led teams in three existing courses in the areas of sustainability, interior design, and facility management in a service learning capacity. The teams 
were comprised of about 40 graduate and undergraduate students. The unique design of the research involved a residential field study in situ with the involvement of student teams from two upper division (third- and fourth-year undergraduate) university classes. Prior to conducting the lighting tests with community participants, the students underwent some training that equipped them to take UV and lighting measurements. The student-researchers followed the industry recommended scientific steps of measuring existing UV light levels to conduct the on-site lighting research (Rea, 2000). Each undergraduate student team was assigned a separate residential room to study. Two tools were used to measure UV presence in each location: (1) a Mannix UV-340 meter and (2) blue wool dosimeters. The second tool consisted of strips of specially dyed wool cloth adhered to a card; each textile strip faded at a different rate, thus allowing students to estimate the level of potential textile fading in the tested area (see Figure 1). A graduate student leader trained the undergraduate students in appropriate measurement procedures.

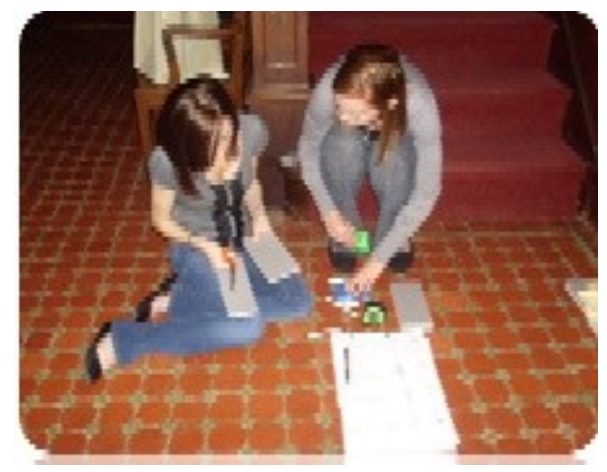

FIGURE 1

STUDENTS PREPARING BLUE WOOL DOSIMETERS FOR PLACEMENT IN HISTORIC HOME ROOMS.

Students learned how to measure and grid the residential floor plans in 2'x2' sections (see Figure 2). At each grid intersection, UV-level meter readings were taken, both on the floor and at 2'-6" above the floor. The second measurement represented the "workplane," which is a common height for tables, desks, and other work surfaces. By analyzing residential lighting issues within a real-world situation, the students gained an understanding of residential applications. After the lighting measurements and fading data were collected, a graduate student team leader developed computer aided design (CAD) drawings of the studied areas of the homes (see Figure 3). 


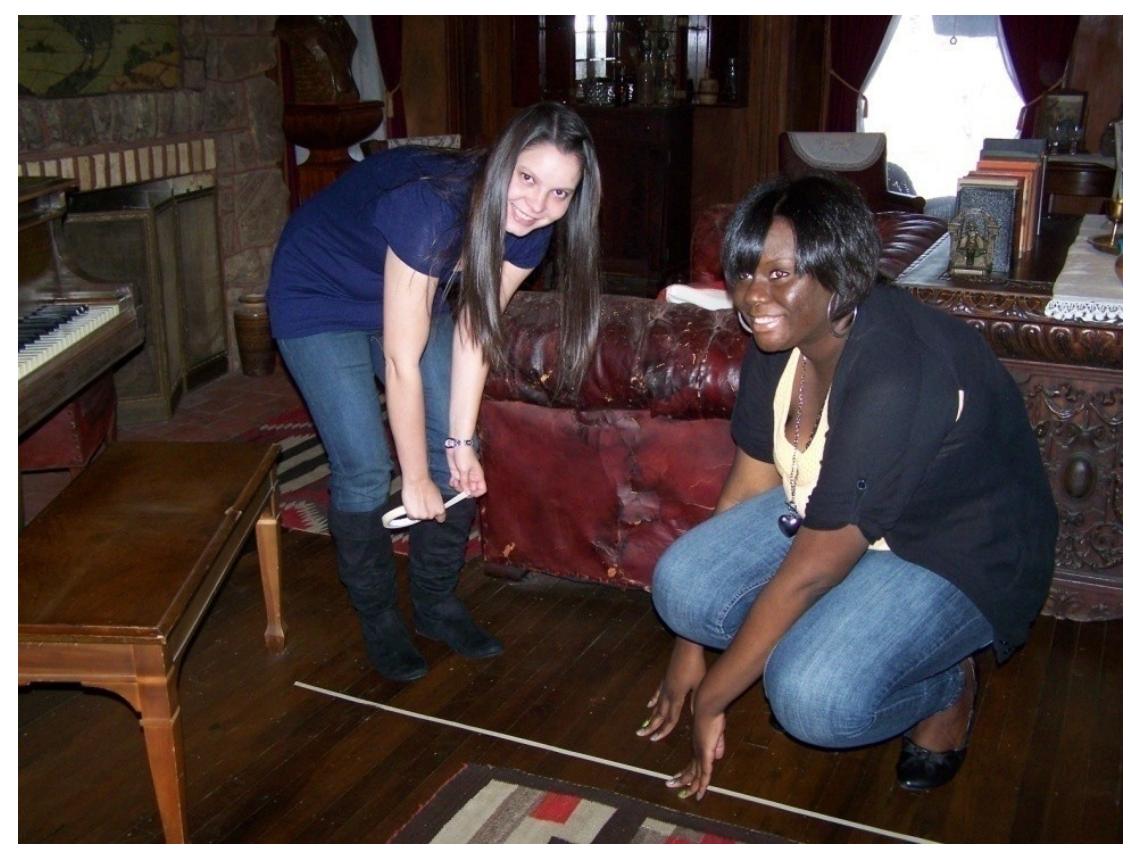

FIGURE 2

STUDENTS MARKING A GRID FOR LIGHTING MEASUREMENTS.

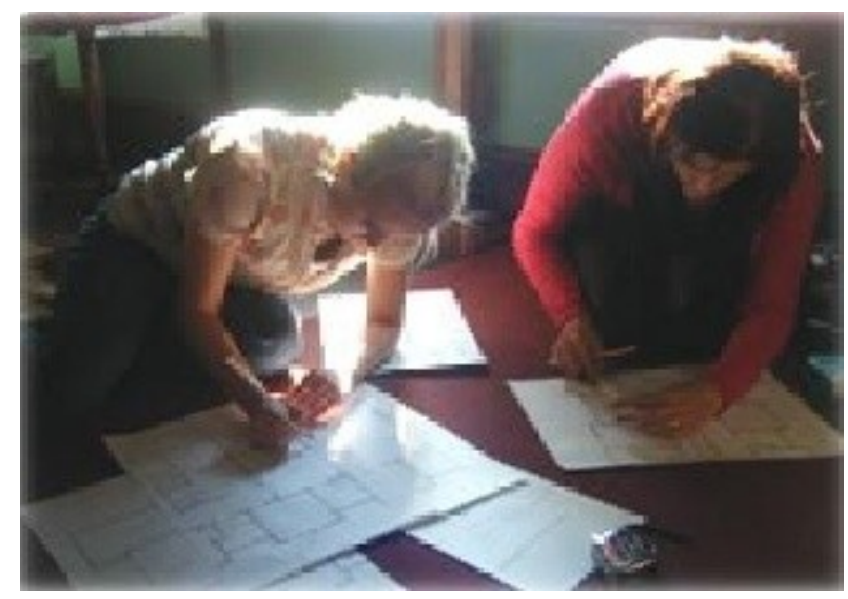

FIGURE 3

RECORDING UV LIGHT MEASUREMENTS ON FLOOR PLANS IN HISTORIC HOME.

In addition to working with fellow students while gathering measurements of the lighting levels, the students also worked closely with the museum staff. The students gained experience in problem-solving activities, by working under the supervision of the state historical society staff to protect the home's priceless and historic museum artifacts during the data collection process. These artifacts - many of them composed of textiles, wood, or paper-also contained "fugitive” dyes, which are subject to degradation from ultraviolet light. Student researchers respected the museum's existing historic preservation techniques, which included avoiding direct, ungloved contact with museum artifacts and furnishings. Students worked in close proximity to priceless 
treasures and learned to value the integrity of the museum artifacts. This exposure to a real-world situation was valuable to the students, because it required them to think critically about their actions. Although the methodology employed to gather on-site measurements was minimally hazardous to the existing environment, some potential for damage to historic artifacts did exist, particularly in the process of taping the measurement grid over and around fragile textiles. Students engaged in critical thinking, in order to determine how to accomplish their goal of data collection, while protecting the museum's irreplaceable artifacts. Additionally, critical thinking was required, in order to use classroom knowledge and on-site experience to determine the optimal placement of dosimiters to measure UV damage over time. Because the museum had not previously established its own standard for UV levels, the students compared the measured UVlevel meter readings to industry standards for home and museum lighting (Rea, 2000). The students made recommendations that were shared with the museum curator, so adjustments could be made in the artificial and natural lighting. This type of research documentation offers minimal risk for the museum and is a way for the university to build a partnership with the museum staff. According to a service learning and historic preservation organization, "Many partners begin with a low-risk project or event that establishes trust and builds momentum with an early success. Over time, larger and more formal partnerships may emerge" ${ }^{\text {. }}$

The existing UV measurements were recorded and assessed in October and November of 2009. A pre-test survey, task lighting assessment, educational session, and post-test survey were administered to participants to collect data during the winter of 2010. These activities identified consumers' perceptions of three different lighting types (incandescent, CFL, and LED). A student-led informational presentation immediately followed the field study and educated research participants on sustainable residential lighting alternatives. Most of the participating graduate and undergraduate college students were concurrently enrolled in environmental sustainability classes and implemented this research as part of the class curriculum requirements.

The two data collection sites were located in counties with marginalized populations that fell below state and national income averages. The data in Table 1 show that these two counties had higher percentages of Native Americans than the national statistic. Descriptive statistics of the research participants showed that almost $60 \%$ self-identified as being from rural areas and small towns in a Midwestern state in the U.S. About $13 \%$ of respondents were both minority and from a rural area or a small town.

TABLE I

DEMOGRAPHIC COMPARISON: COUNTY, STATE, AND NATION, 2008

\begin{tabular}{llllll}
\hline Region & $\begin{array}{l}\text { \% of } \\
\text { population, } \\
\text { Native } \\
\text { Americans }\end{array}$ & $\begin{array}{l}\text { \% of } \\
\text { participants, } \\
\text { Americans }\end{array}$ & $\begin{array}{l}\text { \% of population } \\
\text { below poverty } \\
\text { level }\end{array}$ & $\begin{array}{l}\text { \% of } \\
\text { participants, } \\
\text { below poverty } \\
\text { level }\end{array}$ & $\begin{array}{l}\text { Median household } \\
\text { income }\end{array}$ \\
\hline Field Test County 1 & 12.4 & 12.2 & 15.8 & 25.7 & $\$ 39,489$ \\
Field Test County 2 & 4.6 & 11.5 & 18.7 & 34.6 & $\$ 39,364$ \\
State* & 8.0 & ---- & 15.7 & --- & $\$ 42,836$ \\
National* & 1.0 & --- & 13.2 & --- & $\$ 52,029$ \\
\hline
\end{tabular}

*Source: State and County QuickFacts, 2008

The convenience sample of participants lived in or near the communities of the two selected sites and included almost all of the college students who were assisting in the service learning 
project. The university Institutional Review Board approved the invitation of these participants to the two home sites for the purposes of the study. The participants' ages ranged from 18 to 83.

The multi-part field study took about an hour to complete. Participants were instructed to complete a pre-test survey on their awareness of the three different lighting types. They were then asked to sit in a chair, under a floor lamp containing one of the three (undisclosed) lighting types. Participants were assigned a reading and writing task and then asked to write their evaluations of: 1) the ease of reading and writing; and 2) the characteristics of the lighting under which they performed the tasks. Each participant repeated this process in three separate lighting settings consecutively. A total of 100 usable surveys were collected at both state-owned homes.

\section{FINDINGS}

\section{Field Study Findings}

Tables II-VIII show the number of participants and their level of agreement for each of the questions about the three lighting types. The row counts may not total 100, because not all participants completed every question.

TABLE II

PARTICIPANTS’ EVALUATIONS OF LIGHTING TYPES IN RELATION TO READING TASKS.

Question 1: $\quad$ Based on my experience with the reading/writing activity, I feel that the lighting in the light testing area allows me to see clearly to read.

\begin{tabular}{cccccc}
\hline $\begin{array}{c}\text { Lighting } \\
\text { Type }\end{array}$ & $\begin{array}{c}\text { Strongly } \\
\text { Agree }\end{array}$ & $\begin{array}{c}\text { Somewhat } \\
\text { Agree }\end{array}$ & $\begin{array}{c}\text { No } \\
\text { Opinion }\end{array}$ & $\begin{array}{c}\text { Somewhat } \\
\text { Disagree }\end{array}$ & $\begin{array}{c}\text { Strongly } \\
\text { Disagree }\end{array}$ \\
\hline $\begin{array}{c}\text { Incandescen } \\
\text { t }\end{array}$ & 63 & 32 & 3 & 2 & 0 \\
CFL & 53 & 36 & 2 & 5 & 3 \\
LED & 12 & 41 & 5 & 34 & 7 \\
\hline
\end{tabular}

TABLE III

PARTICIPANTS’ EVALUATIONS OF LIGHTING TYPES IN RELATION TO WRITING TASKS.

Question 2: $\quad$ Based on my experience with the reading/writing activity, I feel that

\begin{tabular}{cccccc}
\hline $\begin{array}{c}\text { Lighting } \\
\text { Type }\end{array}$ & $\begin{array}{c}\text { the lighting in the light testing area allows me to see clearly to write. } \\
\text { Agree }\end{array}$ & $\begin{array}{c}\text { Somewhat } \\
\text { Agree }\end{array}$ & $\begin{array}{c}\text { No } \\
\text { opinion }\end{array}$ & $\begin{array}{c}\text { Somewhat } \\
\text { Disagree }\end{array}$ & $\begin{array}{c}\text { Strongly } \\
\text { Disagree }\end{array}$ \\
\hline $\begin{array}{c}\text { Incandescen } \\
\text { t }\end{array}$ & 67 & 27 & 4 & 2 & 0 \\
CFL & 57 & 37 & 1 & 4 & 0 \\
LED & 21 & 46 & 5 & 23 & 4 \\
\hline
\end{tabular}


TABLE IV

PARTICIPANTS' EVALUATIONS OF LIGHTING TYPES IN RELATION TO BRIGHTNESS OF ILLUMINATION.

\begin{tabular}{cccccc}
\hline Question 4: & \multicolumn{5}{c}{ The lighting in the light testing area is bright. } \\
\hline $\begin{array}{c}\text { Lighting } \\
\text { Type }\end{array}$ & $\begin{array}{c}\text { Strongl } \\
\text { y } \\
\text { Agree }\end{array}$ & $\begin{array}{c}\text { Somewhat } \\
\text { Agree }\end{array}$ & $\begin{array}{c}\text { No } \\
\text { opinion }\end{array}$ & $\begin{array}{c}\text { Somewhat } \\
\text { Disagree }\end{array}$ & $\begin{array}{c}\text { Strongly } \\
\text { Disagree }\end{array}$ \\
\hline $\begin{array}{c}\text { Incandescen } \\
\text { t }\end{array}$ & 19 & 40 & 4 & 29 & 8 \\
CFL & 17 & 37 & 5 & 28 & 13 \\
LED & 1 & 6 & 4 & 40 & 48 \\
\hline
\end{tabular}

TABLE V

PARTICIPANTS’ EVALUATIONS OF LIGHTING TYPES IN RELATION TO PLEASING ILLUMINATION.

\begin{tabular}{cccccc}
\hline Question 6: & \multicolumn{5}{c}{ The lighting in the light testing area is pleasing. } \\
\hline $\begin{array}{c}\text { Lighting } \\
\text { Type }\end{array}$ & $\begin{array}{c}\text { Strongl } \\
\text { y } \\
\text { Agree }\end{array}$ & $\begin{array}{c}\text { Somewhat } \\
\text { Agree }\end{array}$ & $\begin{array}{c}\text { No } \\
\text { opinion }\end{array}$ & $\begin{array}{c}\text { Somewhat } \\
\text { Disagree }\end{array}$ & $\begin{array}{c}\text { Strongly } \\
\text { Disagree }\end{array}$ \\
\hline $\begin{array}{c}\text { Incandescen } \\
\text { t }\end{array}$ & 25 & 62 & 3 & 6 & 2 \\
CFL & 22 & 56 & 9 & 9 & 3 \\
LED & 9 & 29 & 21 & 32 & 7 \\
\hline
\end{tabular}

\section{TABLE VI}

PARTICIPANTS’ EVALUATIONS OF LIGHTING TYPES IN RELATION TO OVERALL ILLUMINATION.

\begin{tabular}{cccccc}
\hline Question 7: & \multicolumn{5}{c}{ The quality of the lighting in light testing area is good. } \\
\hline $\begin{array}{c}\text { Lighting } \\
\text { Type }\end{array}$ & $\begin{array}{c}\text { Strongl } \\
\text { y } \\
\text { Agree }\end{array}$ & $\begin{array}{c}\text { Somewhat } \\
\text { Agree }\end{array}$ & $\begin{array}{c}\text { No } \\
\text { opinion }\end{array}$ & $\begin{array}{c}\text { Somewhat } \\
\text { Disagree }\end{array}$ & $\begin{array}{c}\text { Strongly } \\
\text { Disagree }\end{array}$ \\
\hline $\begin{array}{c}\text { Incandescen } \\
\text { t }\end{array}$ & 29 & 58 & 3 & 8 & 0 \\
CFL & 25 & 55 & 5 & 11 & 3 \\
LED & 7 & 26 & 10 & 49 & 7 \\
\hline
\end{tabular}

TABLE VII

PARTICIPANTS' EVALUATIONS OF LIGHTING TYPES IN RELATION TO WILLINGNESS TO TRY. Question 9: $\quad$ If budget were not a concern, I would try this type of lighting in my

\begin{tabular}{cccccc}
$\begin{array}{c}\text { Lighting } \\
\text { Type }\end{array}$ & $\begin{array}{c}\text { Strongly } \\
\text { Agree }\end{array}$ & $\begin{array}{c}\text { Somewhat } \\
\text { Agree }\end{array}$ & $\begin{array}{c}\text { No } \\
\text { Opinion }\end{array}$ & $\begin{array}{c}\text { Somewhat } \\
\text { Disagree }\end{array}$ & $\begin{array}{c}\text { Strongly } \\
\text { Disagree }\end{array}$ \\
\hline $\begin{array}{c}\text { Incandescen } \\
\text { t }\end{array}$ & 30 & 42 & 15 & 9 & 4 \\
CFL & 24 & 51 & 9 & 14 & 2 \\
LED & 4 & 29 & 15 & 28 & 23 \\
\hline
\end{tabular}


TABLE VIII

PARTICIPANTS’ EVALUATIONS OF LIGHTING TYPES IN RELATION TO WILLINGNESS TO BUY.

\begin{tabular}{cccccc}
\hline Question 10: & \multicolumn{6}{c}{ If budget were not a concern, I would buy this type of lighting for my } \\
home.
\end{tabular}

\section{Field Study Discussion}

The participants were asked if the lighting allowed them to adequately perform certain tasks. Although the majority of the participants clearly agreed that incandescent and CFL lamps allowed them to see clearly to read, opinion was more divided on LEDs, with only slightly more respondents agreeing than disagreeing (see Table II). Similarly, a large percentage (94\%) of the participants agreed that incandescent and CFL lamps allowed them to see clearly to write. They were divided on the ease of writing under an LED bulb, but two-thirds of the participants agreed (see Table III).

Next, the participants were asked whether the lighting possessed certain attributes that may affect task performance. When they were asked whether the light was bright, opinions were divided on incandescent and CFL, but for LEDs a clear majority (88\%) disagreed (see Table IV). This may imply that the available LED light used in this study lacked sufficient light output compared to the incandescent and CFL bulbs used in this study.

The participants were then asked to evaluate the quality of the lighting, using the terms, pleasing and good. When asked whether the light was pleasing, the majority agreed that incandescent and CFL were pleasing, but opinion was evenly divided for LED (see Table V). Similarly, the majority agreed that the lighting at the incandescent and CFL stations was good, while opinion was more divided for the LED, with a slight majority (56\%) disagreeing (see Table $\mathrm{VI})$.

Lastly, the participants were asked whether they would be willing to try or buy the different types of lighting. About three-fourths agreed that if budget were not a concern, they would be willing to try incandescent and CFLs in their homes. Opinion was divided on LEDs (see Table VII), with more disagreeing (51\%) than agreeing (33\%). Similarly, a majority agreed that if budget were not a concern, they would be willing to buy incandescents and CFLs for their home, while opinion was divided on LEDs, with more disagreeing than agreeing (see Table VIII). Based on the data in Tables VII and VIII, it appears that participants were similarly satisfied with two of the lighting types: incandescent and CFL. If consumers have few perceived differences between a nonsustainable lighting option (incandescent) and a more sustainable lighting option (CFL), then the consumer's decisions may be based primarily on economic differences. Thus, consumer education emphasizing return on investment is important during the decision-making process.

\section{Demonstration}

An objective of the service learning activity was to enhance the welfare of communities through educational demonstrations. One of the declared objectives of this EPA-funded study was to employ student leaders; therefore, one graduate student gave the on-site educational 
presentations. Participants in the study were given an educational presentation on the three different lighting types by the graduate student leader, modeling behavior for the undergraduate participants, after they completed the task surveys at the lighting stations. The demonstration contained illuminated displays of incandescent, CFL, and LED lighting types for closer examination. Sample bulbs and their packaging were available for comparing light output or lumens and energy used. The presenter offered participants several fact sheets on lighting topics, ranging from energy costs to safe disposal methods. After explaining the comparisons, the student presenter responded to questions and concerns from the participants. The student-led educational presentation generated many questions from the participants, and the presenting student was challenged to think critically to respond to the questions. Thus, reciprocal learning occurred. The student presenter also learned about the needs and concerns of the community members, which is integral to service learning.

Regardless of the participants' level of household income, the educational session increased consumer awareness of the economic benefits and the knowledge that adopting sustainable lighting decreases solid waste in municipal landfills. Armed with new knowledge, the participants can potentially influence hundreds of additional consumers. With increased knowledge of sustainable lighting, they may voluntarily serve as sustainable lighting advocates for friends and family.

\section{Educating Consumers beyond the Participants}

As part of the reflective learning that should accompany service learning projects, the student teams created electronic presentations that examined the value of the service learning activity and documented the field study through photographs. The electronic presentations were shown to the class and one was chosen to be used at the U.S. Environmental Protection Agency's People, Prosperity, and Planet (P-3) National Student Design Expo (NDSE) competition in April 2010. The NDSE competition was a three-day, hands-on exhibit held at the national mall in Washington D.C. The students staffed the booth and explained their service learning project to the hundreds of people visiting the booth at the public event. In addition, a student-created poster that described the research process was displayed at booth. The Expo attracted more than 7,000 people and presented a significant opportunity to educate consumers beyond the participants about sustainable lighting.

A five-minute documentary video was permanently linked to the college website that continues to educate hundreds of consumers. The video clearly explains the research process and presents an interview with a participating graduate student, as well as the faculty researchers, including a resident Native American educator. The research documentary provides further opportunities to educate consumers beyond the participants. To date, more than one hundred site visitors have viewed the video.

\section{Reflective Learning}

The service learning experience enhanced the students understanding of the benefits of sustainable lighting. This resulted in more effective action, such as the planned adoption of CFL and LED lights. Because they have experienced sustainable lighting firsthand, these students are likely to encourage their associates to consider adopting sustainable lighting alternatives. Student response to the project was generally positive. One graduate student reflected that, "the opportunity to work with the public was very valuable to me, because we hear teachers talking about sustainability all the time, so we assume that everyone knows about these things. It was 
sobering and exciting at the same time, to talk with community members about lighting technology." The same student later commented, "The most exciting part of this project was getting to put what I'd learned in class to use in the real world and to see that what we were doing really made a difference to other people.”

\section{Learning Outcomes Assessment}

According to the National Service-Learning Clearinghouse ${ }^{9}$, most service learning activities have common program characteristics that are a result of a student's engagement in the process. To evaluate the effectiveness of this service learning activity, the student learning outcomes were compared to several common characteristics of service learning. The common service learning characteristics and relevant student outcomes during the residential lighting study are identified in Table IX. The table provides evidence supporting the value of the service learning process, as it related to the lighting study.

TABLE IX

CHARACTERISTICS OF SERVICE LEARNING EXPERIENCES AND RELATED RESEARCH ACTIVITIES

\begin{tabular}{|c|c|}
\hline $\begin{array}{l}\text { Common characteristics of } \\
\text { service learning experiences }\end{array}$ & Student outcomes related to the residential lighting study \\
\hline $\begin{array}{l}\text { They are positive, meaningful, and } \\
\text { real to the participants }\end{array}$ & $\begin{array}{l}\text {-Understanding sustainable lighting behaviors that will result in greater } \\
\text { prosperity for the people and planet. }\end{array}$ \\
\hline $\begin{array}{l}\text { Cooperative experiences; exhibit } \\
\text { teamwork }\end{array}$ & $\begin{array}{l}\text {-Working with museum staff in the state-owned homes; } \\
\text { - Functioning as a team member throughout the field study and demonstration } \\
\text { processes; } \\
\text { •Developing leadership skills through graduate students training } \\
\text { undergraduate students in the use of sensitive, scientific testing equipment. }\end{array}$ \\
\hline $\begin{array}{l}\text { Community involvement and } \\
\text { citizenship }\end{array}$ & $\begin{array}{l}\text { - Communicating sustainable lighting alternatives to county residents through } \\
\text { educational seminars in situ; } \\
\text { - Learning about the legacy of the community through exposure to locate and } \\
\text { historic museum artifacts; } \\
\text { •Communicating UV field measurements to museum curators for historic } \\
\text { artifact preservation. }\end{array}$ \\
\hline $\begin{array}{l}\text { Complex problems in complex } \\
\text { setting }\end{array}$ & $\begin{array}{l}\text {-Studying historic artifact preservation and documenting existing lighting } \\
\text { conditions through field measurements. }\end{array}$ \\
\hline Problem solving opportunities & $\begin{array}{l}\text { - Determining actual economic and environmental benefits of sustainable } \\
\text { lighting. }\end{array}$ \\
\hline $\begin{array}{l}\text { Understand in the specific context } \\
\text { of the service learning in relation to } \\
\text { the community challenges }\end{array}$ & $\begin{array}{l}\text {-Understanding and appreciating concerns of county residents during } \\
\text { educational session presentations; } \\
\text { •Experiential learning within the parameters of a museum setting in a rural } \\
\text { county. }\end{array}$ \\
\hline Critical thinking & $\begin{array}{l}\text { •Examining and comparing sustainable and nonsustainable lighting } \\
\text { alternatives for residential applications; } \\
\text { •Comparing UV lighting levels of homes to industry standards; } \\
\text { •Developing a lighting report of existing conditions that were shared with } \\
\text { curators. }\end{array}$ \\
\hline Real-world application & $\begin{array}{l}\text { - Research project management in a residential setting through measuring } \\
\text { lighting levels using UV meters and blue wool fading cards; } \\
\text {-Developing professional practices through data collection in close proximity } \\
\text { to priceless and fragile historic furnishings, while preserving the integrity of } \\
\text { the museum artifacts. }\end{array}$ \\
\hline Deeper learning with uncontrived & •Experiential learning within a field study setting and processing genuine \\
\hline
\end{tabular}




\begin{tabular}{ll}
\hline results & feedback from community participant stakeholders; \\
& - Developing communication skills through educational sessions with \\
& participants; \\
& Experiencing professional growth through developing CAD drawings of \\
& metered sections of historic homes using real data. \\
\hline Personally and emotionally & Experiencing unique and new learning; \\
meaningful & Understanding the value of extra-curricular activities and teamwork in \\
& creating meaningful educational experiences; \\
& $\bullet$ Exhibiting reflective learning through team presentations of research \\
& activities at the semester's conclusion. \\
\hline Learning leads to effective action & Educating consumers beyond the study participants through electronic slide \\
& presentations and research poster for presentation table at the National \\
& Student Design \\
& $\bullet$ Expo (attended by large numbers of visitors); \\
& $\bullet$ Understanding the importance of encouraging others to adopt sustainable \\
& lighting after experiencing it firsthand; \\
& $\bullet$ Expanding awareness of sustainable lighting by participating in the field \\
& study and educational sessions. \\
\hline
\end{tabular}

\section{DISCUSSION}

The research combined the testing of a new in-situ methodology with service learning applications that benefitted students, the county residents, the historic home staff, and the local Native American population. Students were engaged in active learning at all stages of the research and interacted with the Native American population that included employees of the historic homes, other students, county residents, and a Native American researcher who was familiar with the particular cultural narrative of the Native Americans in the selected counties. Student teams gained a greater understanding of the Native American culture not only from personal interaction, but also from working in close proximity to the Native American artifacts in the historic home. Student teams produced and presented summaries of their service learning participation through visual documentation of their experiences, as well as reflective written comments.

There were a few limitations of the research. One limitation was a modest sample size of 100 participants, selected through convenience sampling. Due to the rural nature of the counties and the rural location of the selected sites, there was some difficulty encouraging voluntary participants to drive to these locations. During one scheduled survey collection opportunity, sleet and snow prevented many county residents from visiting the sites to participate. Another limitation was the lack of availability of a sample LED bulb with sufficient light output to use in task lighting analysis. However, LED bulbs with comparable light output are now commercially available and should be used in future studies.

Future research recommendations include replicating the lighting survey in other counties with even greater percentages of Native American populations. In addition, it is recommended that individual undergraduate reflective learning opportunities be included in the service learning project. As designed, this service learning research accommodated individual reflective learning opportunities for the lead graduate student, but for undergraduate students, the reflective learning occurred within the small teams of students (four per team) rather than as individual learners. It is recommended that all students complete an individual reflection. 
The benefits of the project were widespread and served both local and national populations. The research provided an opportunity to disseminate sustainable lighting information to large numbers of consumers and allowed students to gain experience in scientific data collection. The museum setting was also a unique opportunity, because the students had not been exposed to artifact preservation in their regular coursework. The structured service learning component provided many students with their first opportunity for community involvement with marginalized populations. The positive working relationships with the museum staff resulted in additional possible research partnerships for the future. All of the benefits contributed to a successful blend of service and learning.

\section{Acknowledgment}

Although the research described in this article has been funded wholly or in part by the United States Environmental Protection Agency through grant/cooperative agreement SU834333 to Oklahoma State University, it has not been subjected to the Agency's required peer and policy review and therefore does not necessarily reflect the views of the Agency and no official endorsement should be inferred. Special thanks go to Dr. Jan Johnston for participating in data collection. Thanks are also given to Burns and Ann Hargis, and the Oklahoma Historical Society.

\section{REFERENCES}

${ }^{1}$ Bennich, P., and A. Persson. "Methodology and First Results from End-Use Metering in 400 Swedish Households.” Paper presented at the Conference paper in EEDAL 06: International Efficiency in Domestic Appliances and Lighting Conference, Gloucester, June 2006.

${ }^{2}$ Consortium for Energy Efficiency. "Residential Lighting Fact Sheet." http://www.cee1.org/resrc/facts/rs-lt-fx.pdf (2007).

${ }^{3}$ Cook, Christine C., and Nancy Meredith. "Service Learning for Housing and the Aging." Housing and Society 31, no. 2 (2004): 159-67.Eyler, Janet, and Dwight Giles. Where's the Learning in Service-Learning? $1^{\text {st }}$ ed, The Jossey-Bass Higher and Adult Education Series: Jossey-Bass San Francisco, 1999.

${ }^{4}$ Eyler, Janet and Dwight Giles. Where's the Learning in Service-Learning? ${ }^{\text {st }}$ ed, The JosseyBass Higher and Adult Education Series: Jossey-Bass San Francisco, 1999.

${ }^{5}$ Furco, Andrew. "Service-Learning: A Balanced Approach to Experiential Education." Expanding boundaries: Serving and learning 1, no. 1 (1996): 2-6.

${ }^{6}$ Hegeman, Carol, and Kate O’Flathabhain. “An Overview of Intergenerational Service Learning, Module 1. Foundation for Long Term Care.” (2010).

${ }^{7}$ Honnet, Ellen and Susan Poulsen. "Principles of Good Practice for Combining Service and Learning.” Wingspread Special Report. Racine, WI. The Johnson Foundation (1989).

${ }^{8}$ National Service-Learning Clearinghouse. "Service-Learning and Historic Preservation: First Steps.” http://www.servicelearning.org/instant info/historic preservation/steps.php (2010). ${ }^{9}$ National Service-Learning Clearinghouse. "What Are the Characteristics of Service-Learning?” http://www.servicelearning.org/what is service-learning/characteristics (2004).

${ }^{10}$ Osram Sylvania. "Sylvania Socket Survey, Second Annual." http://assets.sylvania.com/assets/Documents/2009 SYLVANIA Socket Survey.d81a552e-cb6b4779-9e56-5da47e838c7f.pdf (2009). 
${ }^{11}$ Rea, M., (Ed.). The IESNA lighting handbook (9th ed.). New York: Illuminating Engineering Society of North America, 2000.

${ }^{12}$ Reynolds, Travis W., Thomas P. DeSisto, Byron Murray, and Jane Kolodinsky. "Promoting Energy Efficiency in Small Island States: Overcoming Barriers to the Adoption of Compact Fluorescent Lighting in Saint Lucia.” International Journal of Consumer Studies 31, no. 5 (2007): 460-67.

${ }^{13}$ State and County QuickFacts. "U.S. Census Bureau." http://quickfacts.census.gov/qfd/states/40000.html (2008).

${ }^{14}$ Wesley, Allan and David Ryan "Compact fluorescent lights (CFLs) in Canada." [CBEEDAC 2006-RP-03, a publication of the Canadian Building Energy End-Use Data and Analysis Centre]. http://www.cbeedac.com/publications/documents/CFLpaper2006-rp03.pdf (2006).

${ }^{15}$ Wilhite, Harold, Hidetoshi Nakagami, Takashi Masuda, Yukiko Yamaga, and Hiroshi Haneda. "A Cross-Cultural Analysis of Household Energy Use Behaviour in Japan and Norway.” Energy Policy 24, no. 9 (1996): 795-803.

${ }^{16}$ Wilms, Wim and Evan Mills. "Analysis of Price and Nonprice Factors Influencing the Adoption of Compact Fluorescent Lamps by European Households.” Proceedings of Right Light 2. pp 563581, 1993. 